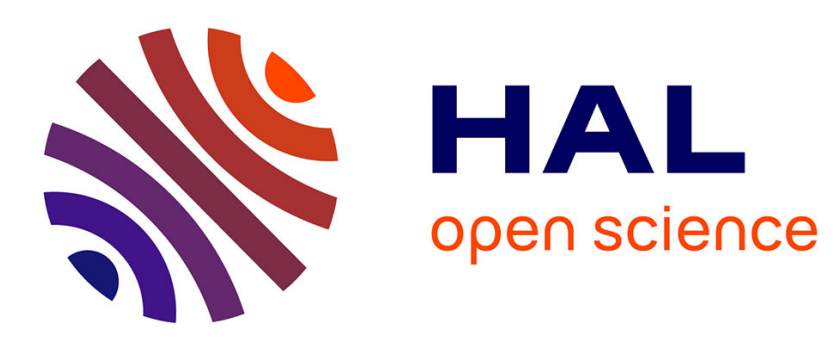

\title{
Theoretical substantiation of the model of borrowing rights-terminating facts
}

Anatoliy V Kostruba, Oleh S Hyliaka

\section{To cite this version:}

Anatoliy V Kostruba, Oleh S Hyliaka. Theoretical substantiation of the model of borrowing rightsterminating facts. Rivista Di Studi Sulla Sostenibilita, 2021, 2, pp.189-203. 10.3280/RISS2020-002S1014 . hal-03180512

\section{HAL Id: hal-03180512 https://hal.science/hal-03180512}

Submitted on 27 Mar 2021

HAL is a multi-disciplinary open access archive for the deposit and dissemination of scientific research documents, whether they are published or not. The documents may come from teaching and research institutions in France or abroad, or from public or private research centers.
L'archive ouverte pluridisciplinaire HAL, est destinée au dépôt et à la diffusion de documents scientifiques de niveau recherche, publiés ou non, émanant des établissements d'enseignement et de recherche français ou étrangers, des laboratoires publics ou privés. 


\title{
Theoretical substantiation of the model of borrowing rights-terminating facts
}

\author{
by Anatoliy V. Kostruba ${ }^{*}$ Oleh S. Hyliaka ${ }^{* *}$
}

\begin{abstract}
The relevance of the research is determined by the fact that it is necessary to differentiate the possibility of applying rights-terminating facts not only in general constructs of the civil branch of legislation but also in a number of private practices of sub-industries regulating general socio-economic relations. Such differentiation can contribute to the sustainable development of the civil sector of legislation. The aim of the article was to show new constructions in connection with the judicial system and the system of socio-economic forecasting. The main importance of legal consists in the fact that they can be applied in general in the category of civil law and at the same time their role as regulators of the civil branch of legislation is minimized or does not work at all. In this regard, for the termination of legal relations, mainly general constructs of juridical facts without formalization for industry values are used. Such constructions contribute to equality between members of society, which in turn contributes to its development and well-being. It is found that the main task of the formation of the practice of applying rights-terminating facts is to determine the limits of liability of industry-specific legislation. The practical significance of the research is determined by the fact that for the first time the aspects of sectoral planning of the system of application of rights-terminating facts are revealed. The developed model can be applied both in the process of adjudication and in the process of socio-economic development programmers. The novelty of the research is determined by the fact that in the literature, aspects of the formation of industrial legislative grounds for the application of local juridical facts are shown for the first time.
\end{abstract}

Key words: Social security law, Systematisation, Legislation, Legal relations, Rulemaking entities.

\footnotetext{
* Department of Civil Law, Vasyl Stefanyk Precarpathian National University, 57 Shevchenko Str., 76000 Ivano-Frankivsk, Ukraine, e-mail: a.kostruba4537-1@uohk.com.cn.

** Department of Planning and Coordination of Legal Research in Ukraine, National Academy of Legal Science of Ukraine, 70 Pushkinska Str., 61000 Kharkiv, Ukraine.
}

DOI: 10.3280/RISS2020-002-S1014 


\section{Introduction}

One of the conditions for the development and improvement of regulatory acts, including in the field of social security law, is to take into account the objective circumstances of their functioning, financial and organisational measures necessary for their implementation. It is only in this case that it is possible to create an optimal model of legal regulation of social relations that is impossible without studying juridical facts as specific life circumstances, with which the rule of law connects the onset of certain legal consequences, in particular, the emergence and dynamics of legal relations (Hage, 2018).

The science of social security law is perhaps the most dynamic, which is related to the constant improvement of legislation in the field of the population protection from the adverse effects of social risks, which inevitably affects legal relations in this field. One of the manifestations of such dynamism is a significant number of phenomena of objective reality, which are recognised by the rule-making entities conditioning certain legal consequences. Eliminating or improving ways to avoid the negative consequences of social risks can also affect the sustainable development of society. This can be explained by the fact that thanks to social guarantees, people can feel their security, support from the state and feel confident in the future. As a result, this contributes to the formation of a prosperous society. In this regard, one should note the great importance of systematisation of juridical facts in social security law because this make it possible to understand the diversity of this legal phenomenon (van Schooten, 2009).

One should note that the question of systematisation of juridical facts both in general theory of law and within its individual branches is perhaps the most common subject of scientific research. A means of systematisation of juridical facts is a classification, the main task of which is a combination of different elements of this category of law, which can often contradict one other, the identification of such contradictions, their elimination and the creation of a single and clear system (Morawski, 1999). Thus, the systematisation of juridical facts, as the grounds for the emergence of social security legal relations, by classifying them will allow for qualitative and detailed research of them and facilitate pointing out their essential signs and particularities, identifying their influence on the creation of a socially sustainable well-being society.

The aim of the article was to show new constructions in connection with the judicial system and the system of socio-economic forecasting. 


\section{Literature review}

Every phenomenon of objective reality is endowed with certain properties that determine its content and allow to talk about the signs. Such properties are called signs (Baurmann, 2000). In the philosophical dictionary, signs are suggested to be understood as signs of an object or phenomenon that determine the similarity of its carrier to other objects of knowledge or difference from them; property. The set of signs allows to distinguish an object (phenomenon) from other objects (phenomena).

The signs which determine the nature of the object under research are called essential. Essential signs are the basis for the generalisation of objects in the concept and pointing them out among other objects similar to them (Dewitz, 1995; Skrypniuk et al., 2019).

Speaking about the non-standard nature of this sign, it should be noted that the set of facts is a complex of heterogeneous, independent life circumstances, each of which can independently have the meaning of a juridical fact (Yalnazov, 2018). For each branch of law, legally significant consequences in which arise on the basis of complex juridical facts, in connection with which this set differs. For industrial legal relations, the emergence of social risk is not as important as in social security law. The sustainability and relative independence of the investigated sign is reflected in the definition of the content of social risks in the legal norms. Thus, citizens have the right to social services as a type of social security in case of difficult life circumstances that can be caused by disability, age, state of health, social status, life habits and way of life, as a result of which a person partially or completely does not have (has not acquired or lost) the ability or possibility to independently take care of personal (family) life and participate in public life (Coleman, 2013; Makushkin, 2019).

Besides, signs of the juridical facts, as the grounds for the emergence of social and security legal relations, can be divided into generic and specific (van Zanten et al., 2015). In logic, generic is called a sign that is inherent in objects of a certain class, within which there are objects reflected in this concept. The generic sign for these objects is indistinguishable. Specific sign is the property of a certain set of objects of a certain kind. There can be a lot specific sign. It depends on the degree and level of study of the subject. Thus, speaking about signs of the juridical facts as the bases of emergence of social and security legal relations, they can be divided into two large groups: generic and specific (Paliienko et al., 2020).

Generic signs of juridical facts, as the grounds for the emergence of social security legal relations, are those of their features (properties) that determine the similarity of this phenomenon and juridical facts in other branches of law 
(Khadzhyradieva et al., 2019a). At the same time, within each branch of law, juridical facts have certain specific features that distinguish them from the content of this legal category in the sphere of other branches of the legal system. Juridical facts in the sphere of social security law are no exception. It is this circumstance which testifies to the existence of generic signs of the juridical facts as the grounds for the emergence of social security legal relations which are such their features which are different from the properties of juridical facts as the grounds for the emergence and dynamics of legal relations and other legally significant consequences within other branches of law (Wróblewski, 1989).

The definition by legal norm of entities of legal relations between them, objects and juridical facts does not create them in physical space (in fact). Legal norms are only prerequisites for the emergence and formation of juridical facts as grounds for the emergence of real legal relations. Therefore, a non-existent social situation or assumptions about it cannot be an integral part of the juridical fact as the ground for the emergence of social security legal relations. Exclusively real, objective and concrete life circumstances can give rise to socially significant consequences, including in social security law (Rigaux, 1990). Normative signs of juridical facts should include direct or indirect predictability by the legal norm; enshrining in the procedural form established by the legislation; possibility to predetermine the legal consequences provided by legal norms.

When analyzing the signs of juridical facts without singling out their types depending on the aspects of understanding this legal category, it can be concluded that they carry the information about the state of social relations, which are the subject of legal regulation, expressed externally, indicate the presence or absence of certain phenomena of the material world and cause legal consequences provided by law.

When conducting the research of the characteristic features of juridical facts, it should be noted that:

1. By their social nature, juridical facts are life circumstances that cannot by themselves cause legal consequences. This quality is given to them by legal norms, the adoption of which depends on the law-making entity.

2. Juridical facts mediate the movement of legal relations (occurrence, change, termination).

3. Legal facts give rise to legal consequences only in interaction with the legal norms.

4. Indications of legal facts and their description are contained in the hypotheses of legal norms.

Juridical facts are inherent in such characteristics as legality, validity, ability to condition legal consequences, concreteness, informativeness, 
formalisation and effectiveness. However, this position is debatable. Legality and formalisation are not unconditional signs of the juridical facts, such a variety of the juridical facts as actions, is not always lawful. Sometimes a participant of legal relations can commit illegal actions with which the legal norm will also connect approach of these or those legal consequences. By formalisation, as a sign of juridical facts, it is not inherent in such a type of juridical facts as events, since the latter ones do not depend on the will of the person (Toleubai and Kizdarbekova, 2018; Khadzhyradieva et al., 2019b).

However, from our point of view, such criticism is not substantiated enough, especially in the field of social security law. Indeed, legally significant circumstances that give rise to legal consequences are not always lawful, however, the content of this sign is not the compliance of acts with the requirements of legal norms, but only recognition of such actions and acts by legal norms legally significant, that is those which give rise to certain legal consequences. As for another example, one should note that, although events do not depend on the will of people, nevertheless, it is only after proper registration of their consequences it could be said that this event is a juridical fact. Thus, for example, a technogenic accident by itself does not give rise to any legal consequences which overcoming would be regulated by the norms of social security law (Kiikeri, 2001).

Thus, based on the research of certain scientists (Hunt and Mostyn, 2020; Marques Martins, 2020; Tuzet, 2020), one can conclude that generic (general) signs of legal facts, as the grounds for the emergence of the social security legal relations include:

1) concreteness which consists only in the possibility of real-life circumstances and phenomena of reality to give rise to legal consequences. Thoughts, emotions and beliefs do not have this property;

2) external expression, which implies the real presence or absence of certain phenomena, since the legal significance of both positive facts that give rise to legal consequences by their presence, and negative ones on the basis of which legal consequences arise in their absence;

3 informativeness, the meaning of which is to bring to the attention of subjects of law the information about the state of social security legal relations;

4) conditionality by legal norms, which implies a dialectical relationship between juridical facts and legal prescriptions: without the legal norm there can be no juridical fact, but without the latter there are no legal consequences;

5) formal certainty which consists in fixing the juridical facts in the procedural form established by the legislation; 
6) heredity, providing for the generation by the juridical fact of legally significant consequences provided for by the legal norm, in particular the emergence of social security legal relations.

At the same time, within each branch of law, juridical facts have certain features that distinguish them from the content of this legal category in the sphere of other branches of the legal system. Juridical facts in social security law are no exception as well.

\section{Materials and methods}

The specificity of the social security legal relations is that they arise in most of the complex set of facts and at the same time - with a special structure. In this regard, methods of comparative law were applied in the research. So, the term "juridical set of facts" was introduced in the theory of legal science for the first time and, in our opinion, the term "actual set of facts" is imperfect and does not reveal the essence of the concept. The use of the concept of "juridical set of facts" focuses the attention on the functional purpose of this legal category, while the concept of "actual set of facts" reflects only the features of its structure (set of facts) (Toh, 2008). The definition of this legal category as "juridical set of facts" will lead to terminological confusion, since the legal science is saturated with other sets which have legal significance (set of legal relations, set of elements of an offence). The use of the word "actual" is an indication that here it is talking about juridical facts (Xiong and Zenker, 2018).

That is why it is more correct to use the concept of "juridical actual set of facts", which will allow to focus the attention on its legal nature, legal properties regarding the consequences and qualitatively distinguish a certain set of facts from other factual complexes that have indirect significance for the establishment of the legal result. In the legal literature, the most common point of view on the juridical actual set of facts as a complex of heterogeneous, independent life circumstances, each of which can have the value of an independent juridical fact. However, an important feature of juridical actual sets of facts, including in social security law, is that the life circumstances, which are included in it (set of facts), create a certain system, the elements of which are interrelated (Hage et al., 2017).

The manifestation of this feature of juridical actual set of facts in social security law is that legally significant consequence (emergence of legal personality, dynamics of social security legal relations and the like) is the result of the whole complex of facts - juridical actual set of facts at large (van Schooten, 2014). In view of the above, it should be concluded that juridical 
actual set of facts in social security law is system of juridical actual set of facts provided by the norms of this branch of law which conditions the emergence and dynamics of industry-specific legal relations and other legally significant consequences.

\section{Results and discussion}

Thus, one of the main signs of juridical facts, as the grounds for the emergence of social security legal relations, is that for the emergence and dynamics of legal relations in this field, in most cases, juridical actual set of facts is necessary, that is the system of juridical facts which gives rise to legal consequences. In this case, this is about a complex of heterogeneous, independent life circumstances, each of which can have the value of an independent juridical fact. One should also note that the role of individual juridical facts in juridical actual set of facts, as the grounds for the emergence of social security relations, can be different. Thus, the elements of juridical actual set of facts can include the actions or events that by themselves have no legal significance (timing) or such specific life circumstances that are legally significant, but do not give rise to any legal consequences. Besides, in the very juridical actual set of facts of social security law, its various elements are not the same in their meaning for the legal consequences they condition. For example, making the decision by a competent entity to provide a person with a specific type of social security is a rights-terminating juridical fact of procedural legal relations, as well as a necessary element of the emergence of material legal relations on providing the person with appropriate monetary payments, social services and the like.

The manifestation of the multifunctionality of juridical facts, as the grounds for the emergence of social security legal relations, is that depending on the type of legal relations, one and the same juridical facts can be in some cases rights-forming, in others - rights-changing or rights-terminating. Thus, for example, the death of a person can be the ground for granting a pension to members of his family in connection with the loss of breadwinner, or changing its size, if there is a deceased person who was dependent on the deceased breadwinner, besides, with the death of a person, in any case, his legal personality terminates, including in social security law. The main element of juridical actual set of facts necessary for the emergence of social security legal relations is the emergence of social risk of the possibility of the emergence of social distress and / or material insecurity enshrined by legislation in the result of the reduction or loss of earnings or other income, need for additional costs that a person (members of his family), as a rule, 
cannot overcome on his own and therefore needs support from state and nonstate authorities and other legal entities.

Emergence, change and termination of legal relations in social security law are related to the enforcement of the human right to social security. Thus, social risk is the ground for the emergence of human right to social security, the implementation of which is possible only in legal relations. It is the emergence of social risk that provides a complex character to social security legal relations as each of these risks (disability, incapacity for work, financial insolvency, job-related accident, birth of a child) since the moment of their emergence is transformed into the relevant juridical fact which is the ground for the emergence of (and often for change or termination as well) industryspecific legal relations. Social risks, if they emerge, are recognised both at the national and international levels, as the ground for the emergence of the human right to social security. Thus, it is the presence of adverse consequences of specific life circumstances that arose in the process of life of a person or family that is a necessary condition for the emergence of social security legal relations and providing the persons exposed to their impact with appropriate support. It is the social risk since the moment of its emergence that predetermines the enforcement of the human right to social security, which is impossible outside the relevant legal relations.

The existence of such a type of social security of the population as indirect social service also testifies to the heredity of social risks. A characteristic feature of such services is that they are not provided monthly or at a time to specific recipients - their provision is aimed at supporting certain categories of the population as a whole, which require mitigation or elimination of the impact on them of adverse consequences of various social risks, and the prevention of such risks through various social programmes (both national and local).

Pointing out the criteria for classification of juridical facts as the grounds for the emergence of social security legal relations has not only theoretical but also practical significance, namely to contribute to their exact and correct enshrining in the legal norms, to identify effective means of impact on social relations which arise from the need to overcome or mitigate the adverse consequences of social risks. In turn, exact and detailed enshrining of juridical facts is of great importance for law enforcement agencies, as it allows to effectively carry out social security of different segments of the population.

One of the criteria for classifying juridical facts in social security law is the character of their consequences. According to this criterion, traditionally, there are rights-establishing, rights-changing and rights-terminating juridical facts. This classification is conditional to some extent, since one and the same 
juridical fact in different situations can have different legal consequences. Thus, the establishment of disability is the ground for the emergence of legal relations on material security and social service and can become the ground for changing pension legal relations. However, this classification does not take into account all the options for the transformation of legal relations in social security law. Rights-restorative juridical facts are the circumstances with which, in most cases, associate the restoration of rights and obligations that had been violated previously. Such juridical facts, as a rule, are court decisions.

Thus, in our opinion, when determining the types of juridical facts in social security law, depending on the character of their consequences, one should talk about rights-establishing, rights-changing, rights-preventive and rights-ceasing juridical facts. As mentioned above, it is the rightsestablishing juridical facts that are of the greatest importance in the mechanism of legal regulation of the right to social security. Juridical facts, as grounds for the emergence of social security legal relations, can be classified according to different criteria, at the same time, it is necessary to dwell on the most common in general theory of law division of juridical facts depending on the presence and character of the volitional element, that is, the significance of the will of the entity for the emergence and dynamics of legal relations. According to this criterion, in both general theory of law and social security law, there are two large groups of juridical facts: actions and events. When classifying juridical facts by volitional, one should talk not about actions, but about acts. One should take into account that an act is a broader concept and includes both actions and inactivity. This point of view is undoubtedly substantiated.

However, taking into account the particularities of industry-specific legal relations, which have a declarative character, it can be concluded that inaction in social security law cannot be the cause of the dynamics of the relevant legal relations. The exception to this rule is the juridical facts that condition the dynamics of procedural legal relations where the manifestation of violation or non-recognition of the right to social protection may be the inaction of the obligated entity. Actions, in turn, are divided into: lawful, that is, those which do not contradict to legal norms; unlawful (offences, delicts).

Traditionally, in the legal literature, lawful actions are divided into (Ponomarenkov et al., 2018):

- legal acts (actions of entities, specifically aimed at the emergence or transformation of legal relations which in turn are divided into acts of entities of private law (authorised entities) and public law (obligated entities)); 
- legal actions (actions which are not specifically aimed at establishing legal consequences, but give rise to their force of direct indication of the law).

They can also be distinguished by subjects (actions of individuals, entities authorised for the social security implementation); branch affiliation (substantive, procedural); by the method of implementation (personally, through a representative); by the method of expression and enshrining (relevant documents). As for the other type of juridical facts in social security law - events, they are also subject to classification depending on origin natural (natural disasters, floods) and social (revolutions, military actions); depending on frequency of events - one-time (the onset of retirement age) and periodic (epidemics); by duration - instant (birth of the child) and longstanding (military actions); by number of participants - personal (industrial accident), collective (release of workers), mass (events with a definite and indefinite number of persons participating in them); depending on the character of the consequences - reverse events (disease) and irreversible (death of the breadwinner) and the like. The particularity of social security legal relations is that, as a rule, their emergence and dynamics are predetermined not by one but several juridical facts which in their totality constitute juridical actual set of facts. It is juridical actual set of facts but not individual juridical facts that predetermines the dynamics of the majority of legal relations in social security law. In this regard, by the sign of the importance for the emergence of legal relations, juridical facts, as the grounds for the emergence of social security legal relations, can be divided into main and secondary.

Thus, the main juridical facts, which are an integral part of rightsestablishing juridical actual sets of facts in social security legal relations are, as a rule, are enshrined in regulatory acts and are the circumstances which predetermine social appointment of relevant legal relations. Such circumstances are the emergence of social risks which include disability, loss of breadwinner, reaching retirement age and the like. Secondary juridical facts in social security law are all other circumstances that are legally significant for the emergence and transformation of social security legal relations. For example, dependence, absence of persons who are obliged to support the disabled one by law.

A certain list of criteria for the classification of juridical facts, as the grounds for the emergence of social security legal relations is not full and can be supplemented by other signs, among which there is the interrelation of legal consequences with the existence of a certain phenomenon or its absence (positive, negative). Thus, the example of positive juridical facts necessary for the emergence of legal relations regarding granting the pension 
due to the loss of a breadwinner is the death of breadwinner, existence of family ties between the deceased one and the future recipient of the pension, his disability and dependence on the deceased one, the presence of the deceased breadwinner's insurance experience of certain duration. Negative juridical facts, as the grounds for the emergence of social security legal relations, can be considered in case where it is the absence of a certain phenomenon that causes certain legal consequences. Depending on time duration, juridical facts, as the grounds for the emergence of social security legal relations, are subdivided into facts of one-time action and facts of statuses.

Legal statuses do not have the meaning of juridical facts, but are only prerequisites for the formation of legal relations and conditions of their emergence. The legal status is still a juridical fact; however, it has no independent legal significance, but is exclusively a constitutive element of the juridical actual set of facts necessary for the emergence, change or termination of the relevant legal relations. Without entering into a discussion about the legal nature of legal statuses in social security law, it should be pointed out that most often it is these phenomena of objective reality, which are lasting in time, that the actual circumstance that determines the emergence and dynamics of legal relations in social security law, in particular, their main type of social security legal relations. So, one can give an impressive list of statuses (for example, pregnancy, temporary incapacity for work, disability, old age, loneliness, poverty, insurance, citizenship and the like), which by themselves do not give rise to legally significant consequences in the field of social protection, however, the emergence and dynamics of social security legal relations and related to them procedural legal relations are possible only in the presence of the following circumstances in conjunction with other important elements of the juridical actual set of facts.

Legally significant consequences in social security law cause in most cases lasting in time juridical facts, that is, facts of statuses the features of which in social security law are long-standing character, occurrence on the basis of actions or events which have independent significance, possibility of repeated application and generation of legally significant consequences only as a part of juridical actual set of facts. Juridical fact-status in social security law is a specific life circumstance arising on the basis of acts or events which have their own legal significance characterised by a long period and the possibility, in conjunction with other juridical facts, to repeatedly give rise to legally significant consequences in the enforcement of the right to social security. Certain criteria for the classification of juridical facts can be applied to this legal category in all branches of law. At the same time, 
when studying juridical facts, as the grounds for the emergence of social security legal relations, one can point out the criteria for the classification of phenomena of the objective reality that gives rise to the relevant relations, which are inherent only in this branch of law. Thus, juridical facts, as the grounds for the emergence of social security legal relations, can be classified depending on the organisational and legal form of social security. This classification allows to take into account the particularities of the emergence of legal relations within certain forms of social security given their legal character, the specifics of financing and management. Organisational and legal forms of social security are compulsory state pension insurance; obligatory state social insurance of employees; social security through direct fund allocations from the state budget; keeping disabled citizens in social institutions of all forms of ownership; targeted social assistance to needy citizens; non-state pension provision; charitable assistance.

Nevertheless, in our opinion, taking into account the reform of the social protection system, allocation of special social security as an independent organisational and legal form of social security which provides for special (different from general) conditions of pension provision of the persons who perform a special type of activity and in this regard are not subject to obligatory state social insurance, as well as the persons who, although subject to social insurance, but the state assumes the responsibility for their increased social security, is unsubstantiated. From our point of view, in modern socioeconomic and political conditions of development of society, it is expedient to talk about the existence of four organisational and legal forms of social security: social insurance, state social assistance, additional social security and non-state social security. The list of organisational and legal forms of social security includes social insurance, state social security, mixed social security, non-state social security. The classification of juridical facts, as the grounds for the emergence of social security legal relations, depending on the types of social security, which is a certain material benefit, in respect of which these legal relations arose, is also meaningful. These include different kinds of monetary payments, social services, social benefits.

Given the content of the object of social security legal relations, two units of legal relations can be distinguished, and consequently, juridical facts, as the grounds for their emergence, change and termination:

- juridical facts in the field of legal relations on implementation of monetary payments as a type of social protection;

- juridical facts in the field of legal relations on implementation of other ("natural") types of social security.

However, given the multiplicity of types of both monetary payments and other types of social security, the next level of the proposed classification, 
according to which, juridical facts in the sphere of legal relations on implementation of monetary payments, as a type of social security, should be divided into juridical facts in the field of pension legal relations, in the field of implementation of social assistance which in turn are divided into juridical facts which condition the emergence and dynamics of legal relations regarding the implementation of insurance payments and monetary payments which financing is effected at the expense of means of the state budget. The types of juridical facts in the field of legal relations concerning other types of social security include juridical facts regarding the implementation of social services, provision of social benefits and housing and utility subsidies, provision of medical care, including free or preferential provision of medications.

\section{Conclusion}

Juridical facts, as the grounds for the emergence of social security legal relations, are a multidimensional legal phenomenon that can be classified according to various characteristics which can be divided into general, those applicable to the classification of juridical facts within each branch of law, and special which can be applied to the systematisation of juridical facts conditioning exclusively the emergence of social security legal relations. Thus, general criteria for classification of juridical facts, as the grounds for the emergence of social security legal relations, are: importance for the emergence of social security legal relations; interrelation of legal consequences with the existence of a certain phenomenon or its absence; dependence on the will of entities; dependence on time duration.

Special criteria for systematisation of juridical facts, as the grounds for the emergence of social security legal relations include organisational and legal form of social security; type of social security. According to the criterion of the importance of the juridical fact for the emergence of social security relations, the latter ones can be main and secondary. According to the interelation of legal consequences with the existence of a certain phenomenon or its absence, juridical facts, as the grounds for the emergence of social security legal relations, are divided into positive and negative.

Depending on time duration, there are two types of juridial facts as the grounds for the emergence of social security legal relations: one-time action; legal facts of statuses. Depending on the presence and character of the volitional element, juridical facts, as the grounds for the emergence of social security legal relations, are divided into: actions (acts); events. Depending on types of social security, juridical facts, as the grounds for the emergence 
of social security legal relations, are divided into those which condition the dynamics of legal relations regarding granting: monetary payments, service, medical care, provision with medication and medical products, social benefits, housing and utility subsidies.

Thus, after conducting this study, it is concluded that the development of the system of legal relations for social security is an important part in ensuring the sustainability of the development of society. Due to the wellcoordinated work of the legal system in the state, the transparency of legal phenomena, this contributes to the confidence of society in the future, and thus can affect its well-being.

\section{References}

Baurmann M. (2000), "Legal authority as a social fact", Law and Philosophy, 19(2): 247-262.

Coleman J. L. (2013), The Architecture of Jurisprudence, in Ferrer Beltrán J., Moreso J. J. and Papayannis D. M., eds., Neutrality and Theory of Law, Springer Netherlands, Dordrecht.

Dewitz S. (1995), Using Information Technology as a Determiner of Legal Facts, in Bankowski Z., White I. and Hahn U., eds., Informatics and the Foundations of Legal Reasoning, Springer Netherlands, Dordrecht.

Hage J. (2018), Of Norms, in Handbook of Legal Reasoning and Argumentation, Springer Netherlands, Dordrecht.

Hage J., Waltermann A. and Akkermans B. (2017), Introduction to Law: Second Edition, Springer Netherlands, Dordrecht.

Hunt I. and Mostyn J. (2020), "Probability reasoning in judicial fact-finding", International Journal of Evidence and Proof, 24(1): 75-94.

Khadzhyradieva S., Hrechko T. and Savkov A. (2019a), "Behavioral insights in public policy: Ukrainian case", Public Policy and Administration, 18(1): 85-99.

Khadzhyradieva S., Hrechko T. and Smalskys V. (2019b), "Institutionalisation of behavioural insights in public policy", Public Policy and Administration, 18(3): 95-113.

Kiikeri M. (2001), Comparative Law in European Legal Adjudication, in Comparative Legal Reasoning and European Law, Springer Netherlands, Dordrecht.

Makushkin S.A. (2019), “Company's personnel motivation”, Espacios, 40(40): 116.

Marques Martins J. (2020), "A system of communication rules for justifying and explaining beliefs about facts in civil trials", Artificial Intelligence and Law, 28(1): 135-150.

Morawski L. (1999), "Law, fact and legal language", Law and Philosophy, 18(5): 461-473. 
Paliienko O., Naumenkova S. and Mishchenko S. (2020), "An empirical investigation of the Fama-French five-factor model", Investment Management and Financial Innovations, 17(1): 143-155.

Ponomarenkov V., Kalashnikova E.B., Korobova, A.P., Petrogratskaya A.A. and Karev D.A. (2018), "Social basis of procedural relations", Journal of Advanced Research in Law and Economics, 9(3): 1092-1097.

Rigaux F. (1990). The Concept of Fact in Legal Science, in Nerhot P., eds., Law, Interpretation and Reality: Essays in Epistemology, Hermeneutics and Jurisprudence, Springer Netherlands, Dordrecht.

Skrypniuk O.V., Onishchenko N.M. and Parkhomenko N.M. (2019), "Awareness in law as strategical direction of legal policy", Journal of Advanced Research in Law and Economics, 10(5): 1534-1540.

Toh K. (2008), "An argument against the social fact thesis (and some additional preliminary steps towards a new conception of legal positivism)", Law and Philosophy, 27(5): 445-504.

Toleubai A.M. and Kizdarbekova A.S. (2018), "The concept of commercial legal entities in Kazakhstan and foreign legislation", Journal of Advanced Research in Law and Economics, 9(7): 2437-2446.

Tuzet G. (2020), "Assessment criteria or standards of proof? An effort in clarification", Artificial Intelligence and Law, 28(1): 91-109.

van Schooten H. (2009), "War as an institutional fact: Semiotics and institutional legal theory", International Journal for the Semiotics of Law - Revue Internationale de Sémiotique Juridique, 22(3): 307-320.

van Schooten H. (2014), "Towards a new analytical framework for legal communication", International Journal for the Semiotics of Law - Revue Internationale de Sémiotique Juridique, 27(3): 425-461.

van Zanten G. V., Nissink P. and Dulfer D. (2015), Fact Based Legal Benefits Services, in Ciuciu I., Panetto H., Debruyne C., Aubry A., Bollen P., ValenciaGarcía R. and Ferri F., eds., On the Move to Meaningful Internet Systems: OTM 2015 Workshops, Springer International Publishing, Cham.

Wróblewski J. (1989), "Proof in law: Legal language and legal institutions", Revue Internationale de Semiotique Juridique, 2(1): 3-16.

Xiong M. and Zenker F. (2018), "Legal facts in argumentation-based litigation games", Argumentation, 32(2): 197-211.

Yalnazov O. (2018). "Fact, Law, and Legal Change", in Precedent and Statute: Lawmaking in the Courts versus Lawmaking in Parliament, Springer Fachmedien Wiesbaden, Wiesbaden. 